\title{
Aristotle and the Classical Paradigm of Wisdom
}

\author{
Costanzo J* \\ Conception Seminary College, United States
}

*Corresponding author: Jason Costanzo, Conception Seminary College, 3514 Bel nor Drive Saint Joseph, MO 64506, United States, Tel: 16313716565; Email: jcostanzo@conception.edu

\section{Research Article}

Volume 4 Issue 3

Received Date: June 07, 2021

Published Date: July 09, 2021

DOI: $10.23880 /$ phij-16000191

\section{Abstract}

The essay examines the ancient Greek origin of philosophy relative to the concept of wisdom. The nature of the sage is first considered. The sage is one who is deemed wise in his or her performances. But what is 'wise' about such performances? The Socratic denial of sage status is considered in reference to this. Socrates concludes that he is not wise as the gods are wise, but that he is wise insofar as he knows that he is not wise. The apparent contradiction is resolved through the distinction between human (finite) and divine (infinite) wisdom. The latter notion is further examined in the works of Aristotle who articulates the "classical paradigm" of philosophy in pursuit of infinite wisdom. The attributes of infinite wisdom are identified, and the essay concludes with a discussion of the sagely performance of infinite wisdom, Aristotle himself serving as the representative example.

Keywords: Wisdom; Classical Paradigm; Aristotle

\section{The Sage as Wise Performer}

Anyone familiar with Diogenes Laertius' Lives of the Eminent Philosophers will no doubt recall the many timeless stories that he tells of the Greek philosophers of ancient times. We hear of Diogenes (the Cynic) who lived and slept in a wine jar (pithos), his natural way of life inspiring the awe of even Alexander the Great. ${ }^{1}$ There is also Zeno of Citium, who following a shipwreck in which he is said to have lost his personal fortune, thereafter entered a bookstore and read a copy of Xenophon's Memorabilia. Inspired by the account of the life of Socrates, he inquired of the bookseller whether anyone in Athens was like this philosopher. It so happened that Crates was passing by, and the bookseller pointed to him. ${ }^{2}$ With that, Stoicism was born.

1 DL, 6.2.31. Diogenes Laertius. Lives of Eminent Philosophers, transl. R.D. Hicks (Cambridge: Harvard University Press, 1972).

2 DL, 7.1.2.
Many other memorable stories are recorded in this work of which I could speak, but it is not the point of this essay to examine such stories here. Instead, I should like to focus on one particular story, found at the very beginning of Diogenes' account. There, the reader will find what amounts to the most remarkable claim of all. In response to purported theories regarding the origin of philosophy (likely floating around during his time), Diogenes states the following:

These authors forget that the achievements which they attribute to the barbarians belong to the Greeks, with whom not merely philosophy but the human race itself began. ${ }^{3}$

Taken from a contemporary perspective, where examples of philosophy can be seen blossoming among the ancient cultures spanning the Americas, Northern Africa, and the larger Eurasian continent, such a view must no doubt be

3 DL, 1.prol.3. 
taken as an instance of cultural bias. Certainly human beings from all cultures and times will have raised philosophical questions about the purpose of life and meaning of existence. Of course, at a very early stage, such practitioners would not have been called philosophers. Among the Greeks, they were instead called 'wise ones' or 'sages' (sophoi). Similar notions are found among other ancient cultures, such as the Chinese shengren, ${ }^{4}$ the Hindu rishi, ${ }^{5}$ the Egyptian rekh, ${ }^{6}$ the Akkadian apkallu, ${ }^{7}$ and so on. The reputed number of the (most renowned) sages has also been of some historical significance, as it tends to be seven. Plato, for example, lists seven sages in the Protagoras, including Thales, Pittacus, Bias, Solon, Cleobulus, Mison, Chilo. ${ }^{8}$ Diogenes cites a slightly different list. ${ }^{9}$ Seven sages are also cited among other ancient traditions.

But who are the sages? Still more, what is a sage? For an answer to these questions, we might turn again to the account given by Diogenes Laertius. Take Thales for example. He is described as an astronomer, ${ }^{10}$ as being the "first to maintain the immortality of the soul",11 as providing "excellent advice on political matters", ${ }^{12}$ as holding that "water is the universal primary substance", ${ }^{13}$ and so on. ${ }^{14}$ For another example, Solon is noted both for his wise utterances and, in particular, political sagacity. He provided the Athenians withlaws, ${ }^{15}$ aided the city in its war against Megara, ${ }^{16}$ and in an act emblematic of Plato's philosopher-king, refused an offer to rule as tyrant of that city. ${ }^{17}$ Wise sayings are also attributed to him, such as

4 Rina Maria Camus (2013) The Wiseman and the Sage: Metaphysics as Wisdom in Aristotle and the Neo-Confucian Scholl of Principle. Frontiers of Philosophy in China 8(1): 121.

5 Mahatma Gandhi, The Essence of Hinduism (Ahmedabad: Nevajivan Publishing House, 1987), p. xiii.

6 Théophile Obenga, Egypt: Ancient History of African Philosophy. in A Companion to African Philosophy, ed. by Kwasi Wiredu (Blackwell Publishing, 2004), p. 33.

7 Erica Reiner, The Etiological Myth of the Seven Sages. Orientalia, 30:1 (1961): 1.

8 Plato, Protagoras, 343ab. All translations for Plato's texts are based upon John M. Cooper and D.S. Hutchinson, Plato: Complete Works (Indianapolis: Hackett Publishing Company, 1997).

9 DL, 1.1.13. For a discussion of the issues surrounding the ancient identification of the sages, see Alden Mosshammer, The Epoch of the Seven Sages. California Studies in Classical Antiquity 9 (1976), 165-180.

10 DL, 1.2.23.

11 DL, 1.2.24.

12 DL, 1.2.25.

13 DL, 1.2.27.

14 For a more complete account, see D. R. Dicks, "Thales," The Classical Quarterly 9:2 (1959), 294-309.

15 D.L., 1.3 .45 \& 1.3.61.

16 D.L., 1.3.46.

17 D.L., 1.3.49.
"Speech is the mirror of action".18 Of Chilon, Diogenes notes that he offered marital advice, wrote songs, and interestingly, that "He was a man of few words (brachylogos)". ${ }^{19}$

Although interesting, it may be objected that the account of the sages given by Diogenes is of mere dilettantes who, akin to Hippias of Elis, wove their own garments. ${ }^{20}$ Further inspection, however, reveals an underlying unity. Classicist Richard P. Martin, for example, argues that the various descriptions of the sages seen in Diogenes and other historical accounts can in fact be classified under three distinct headings, viz., that of poet, political servant, and performer. ${ }^{21}$ The third notion is in fact the most significant. The sages are performers who enact wise accomplishments both in word (wise utterances, proverbs) and in deed (miraculous feats, clever demonstrations, etc.). ${ }^{22}$ Their role as renowned performers is likewise intertwined with the kinds of social actors that they engage with. For this reason, the sages are often seen in the literature interacting with kings, emperors, and other persons of high social-standing. ${ }^{23}$ In Herodotus, for example, Chilon advises the Athenian tyrant Peisistratos, following an omen, to avoid rearing a son of his own..$^{24}$ Alternatively, the wise counsel of Solon to King Croesus became the very words that would later save the King from the funeral pyre following defeat at the hands of the Persian Emperor Cyrus. ${ }^{25}$

Although Martin's classification is no doubt justified by ample textual evidence, a difficulty yet remains. The sages are poets, political servants, and principally, performers. At the same time, however, it cannot be said that such attributes differentiate the sage as performers from other types of performers, such as lyrical poets, orators, despots, not to mention sophists. What then distinguishes the performance of the sage qua sage?

To answer this, we might consider first the nature

\author{
18 D.L., 1.3.58. \\ 19 D.L., 1.4 .72$. \\ 20 Cf., Plato, Hippias Major, 282d6-e8.
}

21 Richard Martin, "The Seven Sages as Performers of Wisdom," in Cultural Poetics in Archaic Greece: Cult, Performance, Politics, ed. by Carol Dougherty \& Leslie Kurke (Oxford University Press, 1998): 112. See also, Richard Martin, "Seven Sages," in The Encyclopedia of Ancient History, ed. by Roger S. Bagnall, Kai Brodersen, Craige B. Champion, Andrew Erskine, \& Sabine R. Huebner (John Wiley \& Sons, 2017). DOI: 10.1002/9781444338386. wbeah30425

22 Martin, The Seven Sages as Performers of Wisdom. p. 117.

23 Martin, The Seven Sages as Performers of Wisdom. p. 116.

24 Herodotus, Histories, 1.59. See also Richmond Lattimore, "The Wise Adviser in Herodotus," Classical Philology 34:1(1939), 24-35. In particular, Lattimore identifies (pp. 24-25) two kinds of advisors within ancient thought, viz., the tragic warner and the practical adviser or counselor.

25 Herodotus, Histories, $1.29-32$ \& 1.86. 
of a performance itself. A performance is a type of social interaction between (a) one who performs and (b) one who views the performance. In matters of social evaluation, it is generally those who view the performance, in the sense of the spectator and audience, who provide an evaluation (i.e., right or wrong) of the quality of what has been performed. If we furthermore take the predicate 'wise' as constituting a value predicate that arises within a social context (akin to 'good', 'right', 'pleasing', 'attractive', and so on), then it follows that it is precisely the spectators and audience who judge that the performance is wise, so that the performer is in turn evaluated as wise. In such evaluations, the type of spectator is no less relevant, as Martin suggests. That a friend or family member should seek one's advice is a different matter than that a renowned politician, king, or emperor should do so. In this, we see why the social status of the spectator is relevant to the historical account of the sages. The advice of the sage is regal advice. But regal advice is a potential indication of wise advice, since it deals with the highest matters pertinent to civil society and the just (or unjust) exercise of power. One who bestows regal advice, especially where such advice proves fruitful, will in general be identified as a wise counselor.

From the above it follows that the sage is not just a wise performer, but in particular one whose performance is deemed wise. The problem, however, is that the definition is circular. The wise performance is deemed wise. But precisely what is wise about such performances?

To answer this question, I return to Diogenes and consider precisely the mishmash of skills that he associates with the sages. For example, in the ancient world, Thales was renowned for having predicted an eclipse that brought to a halt a battle between the Medes and the Lydians on May 28, 585 BCE. ${ }^{26}$ Taken in isolation, the accomplishment is no doubt astounding, particularly during this early stage. But it is not the only accomplishment that Diogenes lists of Thales. To the contrary, Thales is also described as an accomplished metaphysician, politician, poet, and so on. Here Martin's three attributes come to the fore. The accomplishments of Thales were remarkable, but also manifold in character. Similar points may be made for the other sages. Far from being mere dilettantes, the sages are more accurately described as polymaths and Renaissance types whose accomplishments are remarkable and excellent (virtuous) in character. An analogy may be drawn to the ancient heroes of Greek mythology, as Odysseus, who is described by Homer as a man of manifold skill (polymetis) and divers ways (polytropos). ${ }^{27}$ So too the sagely exhibition of wisdom is manifold and

26 Herodotus, Histories, 1.73-74.

27 Homer, Iliad, 21:355; Odyssey, 1:1. diverse according to its kind.

There is, however, a further and perhaps overlooked attribute of the sage. This is seen in the consistent emphasis upon their use of wise sayings, aphorisms, and similar forms of brief utterances. We see this both in Diogenes Laertius (as above noted) as well as in Plato's account of the sages in the Protagoras. There Socrates complains that the great sophist's speeches are simply too lengthy to remember. ${ }^{28}$ This complaint is followed up by a short encomium on the virtue of the Lacaedamonians, and in particular, their utterances, which are noted for laconic brevity (brachylogia tis Lakonike). ${ }^{29}$ But why the emphasis here? Why should Plato (through the mouth of Socrates) direct the reader's attention to such a seemingly insignificant matter?

I note that the scholarly literature surrounding this issue is generally undecided, some holding that Socrates is speaking ironically, opposing such maxims to the longwinded speeches of Protagoras. Others take a different direction. ${ }^{30}$ Suspending judgment on the particulars of the debate, I focus instead on the relevance of the laconic utterance itself. Following historical testimonies, some 147 maxims were purportedly inscribed on the Temple at Delphi. ${ }^{31}$ These maxims (some of which Plato cites) ranged from the well-known "know thyself" (gnothi seauton) to "nothing in excess" (meden agan), as well as other maxims such as "consult the wise" (sophois chro) and "seek wisdom" (philosophos ginou). Although the historical origin of these maxims is generally unknown, later sources, including Diognes Laertius, attribute the sayings to the seven sages. ${ }^{32}$ The reference does not, however, appear altogether amiss, as Plato too links the maxims to the sages, noting that they, "dedicated these as the first-fruits of their lore to Apollo in his Delphic temple." ${ }^{33}$

Regardless of their specific origin, that such maxims should be attributed to the sages, is doubtless significant. The above sayings (as well as the other reputed examples) may in general be classified as moral maxims, which is to say, short, pithy sayings that serve as general rules of conduct. ${ }^{34}$

\footnotetext{
28 Plato, Protagoras, $334 \mathrm{~cd}$.

29 Plato, Protagoras, 343b20.

30 For a summary of the larger discussion, see Christopher Moore, "Spartan Philosophy and Sage Wisdom in Plato's Protagoras," Epoché, 20:2 (2016), 281-305. Delfim F. Leão, "The Seven Sages and Plato," Il quinto secolo. Studi etc. Passignano s (2010), 403-414.

31 For the list of the maxims, see Stobaeus, Anth., 3.1.173.

32 DL, 9.11 .71

33 Plato, Protagoras, 343ab.

34 For a classification of the types of maxims or proverbs that occur in early Greek thought, see Emanuele Lelle, Toward a Classification of Greek Proverbs. Paremia 16 (2007), 139-148.
} 
Such maxims function as ethical imperatives: Do this. Don't do that. ${ }^{35}$ This highlights the fact that they are not to be taken as items of dispute, but rather as moral directives to be reflected upon and put into practice. When seen in the context of Socrates' distaste for long speeches and his remarks regarding his own tendency toward forgetfulness, the laconic utterance inevitably leads us back to Plato's theory of recollection (anamnesis). ${ }^{36}$ Simply stated, as the discussion of this theory lies beyond this essay, the key connection can be found in the relationship between the laconic utterance and later articulations of first principles (archai) found in the works of both Plato (viz., the Ideas) and later Aristotle. These views indicate that a fundamental portion of the truth is in some sense already known to us. The sages likewise exemplify such knowledge by their utterances. For this reason, they are called 'wise'.

\section{Socrates and the Denial of Sage Status}

Although certain fundamental features of wisdom may be identified in the early accounts of the sages, it is nonetheless the case that the account remains incomplete. The question of what is wise in such performances had yet, I contend, to be reflectively considered. For such a consideration, it was necessary that the concept of philosophy should itself be articulated. Indeed, one of the fundamental contentions of this essay, is that the two concepts, viz., wisdom and philosophy, at least in their historical origination, are very much correlative concepts. As the one concept developed, so too the other.

Reflection upon the Greek origin of the concept of philosophy reveals why this is the case. Two particular events stand out in the historical literature: First, it was apparently Pythagoras who coined the term 'philosophy', it seems, out of piety. The story is related in Diogenes Laertius as well as other sources. ${ }^{37}$ Pythagoras ( $\left.6^{\text {th }} \mathrm{BCE}\right)$ is said to have preferred the title of 'lover of wisdom' (philosophos) to the more common epithet 'wise one' or 'sage' (sophos), for the reason that: "no man is wise, but God alone". ${ }^{38}$ Second, there is the example of Socrates, whose story serves as a kind of parallel to that of Pythagoras. These events are related in Plato's Apology. Chaerephon, a loyal friend and follower, is reported to have asked the oracle at Delphi if any man were wiser than Socrates. Her response, usually ambiguous, was

\footnotetext{
35 Or more specifically: One ought to do this. One ought not to do that.

36 See, e.g., Plato's Meno, 80d, as well as the Phaedo, 72e-78b.
}

37 Anton-Hermann Chroust suggests that Heracleitus is in fact the earliest identifiable source for the use of the concept of philosophy. See, AntonHermann Chroust, "Philosophy: Its Essence and Meaning in the Ancient World," The Philosophical Review 56:1 (1947), p. 25.

38 DL, 1.prol.12. that "there was no man wiser". ${ }^{39}$ The ambiguity of the answer, however, would eventually fall upon the ears of Socrates who, believing himself to have no certain knowledge, wondered at such perplexing news. In the attempt to refute the oracle, philosophy at least in concept, may be said to have thereafter begun. ${ }^{40}$

If we accept the veracity of these claims, if only in virtue of their historical significance for philosophy, then we discover something peculiar. Neither Pythagoras nor Socrates are willing to claim the epithet 'wise'. Given the ambiguity, the oracle's response might be read as the suggestion not that no one is wiser than Socrates, inasmuch as he indefatigably denies this (and the Pythia would have perhaps been aware of this fact), but rather that no one is wise. Taken from this perspective, the transitional era may in part be understood in terms of the growing awareness, among the Greeks, precisely of their ignorance. ${ }^{41}$

Still, a difficulty remains. The difficulty is that such a humble denial is not altogether accurate. To the contrary, a case may be made that to some extent, both Pythagoras and Socrates were wise, or at least, were deemed wise by the local Greek population. ${ }^{42}$ History likewise attests to this fact. Although competing accounts of Socrates were in circulation (e.g., Aristophanes' Clouds), his status as a sage must have nonetheless been a present historical phenomenon. In the first place, there is the pronouncement of the oracle itself. That the oracle should recognize Socrates among all others individuals as wisest, points to the fact that his status as wise would have already been in high regard at the time of the pronouncement. ${ }^{43}$ There is furthermore the high social standing of the oracle, inasmuch as this plays an essential part in the already discussed designation of sage-status. Kings and emperors consult the oracle, who in turn, claims that Socrates is wisest among the Athenians. Of course, the pronouncements of the sage are often ambiguous, the

\section{Plato, Apology, 21a.}

40 There are in fact competing theories regarding Socrates' interpretation of the oracle's pronouncement, and the supposed "divine mission" that follows from this. See, e.g., Thomas C. Brickhouse \& Nicholas D. Smith, "The Origin of Socrates' Mission," Journal of the History of Ideas 44:4 (1983), 657-666. Robert Metcalf, "The Philosophical Rhetoric of Socrates' Mission," Philosophy \& Rhetoric 37:2 (2004), 143-166. Daniel W. Graham, "Socrates' Mission," BYU Studies Quarterly 55:4 (2016), 141-159.

41 Which often accompanies perplexity and the search for knowledge.

42 Socrates indicates this fact in his defense: "The fact is, men of Athens, that I have acquired this reputation on account of nothing else than a sort of wisdom. What kind of wisdom is this? Just that which is perhaps human wisdom." (Plato, Apology, 20d)

43 There is some debate regarding the purported date in which these events took place. A recent account identifies the year at $426 \mathrm{BCE}$, which would put Socrates at about 44 years old. See, Daniel W. Graham and Justin Barney, "On the Date of Chaerephon's Visit to Delphi," Phoenix 70:3/4 (2016), 274-289. 
catastrophic misinterpretation of Croesus serving as but one example. ${ }^{44}$ Yet even if the oracle's pronouncement was intended ambiguously, the public elevation that would have resulted from such testimony would have likely been sufficient to elevate Socrates to the status of a sage within the social consciousness of the Greeks of the time.

The second point is that the very act of denying sagestatus is in many ways indicative of sage-status. We might compare such a denial to the sophist who not only accepts the label, but also derives profit from it. ${ }^{45}$ Not only does such an act appear arrogant, but it is also impious, as if one would equate oneself equal to the gods. In contradistinction, a wise person insofar as wise, will deny the label of 'sage' for the very reason that, as Pythagoras earlier stated, the gods alone-or most eminently-are wise.

Still more, the denial of sage status appears as an act emblematic of the sages of old. This story, which is very similar to the account of Socrates, can again be found in Diogenes Laertius. Apparently, a dispute arose among a number of Ionian youths regarding a sacrificial tripod discovered by a fisherman. Unable to decide what to do with the object, they asked the oracle of Delphi, who responded:

Who shall possess the tripod? Thus replies

Apollo: "Whosoever is most wise." 46

Upon hearing this, the youths decided to give the tripod to Thales. But Thales refused to accept the gift, and instead gave it to Solon, who in turn gave it back to Delphi. In a display of both humility and piety, no sage was thus willing to accept the gift.

As a final point, the Socratic denial of sage-status exhibits also self-awareness, this being reflective of the wellknown Delphic maxim "know thyself" (gnothi seauton). Selfknowledge is likewise key to the Socratic denial. Although the Delphic oracle pronounces that Socrates is wise, Socrates in contrast contends that he is not wise:

When I heard the answer, I said to myself, What can the god mean? and what is the interpretation of this riddle? for I know that I have no wisdom, small or great. What can he mean when he says that I am the wisest of men? And yet he is a god and cannot lie; that would be against his nature. After a long

\footnotetext{
44 Herodotus, Histories 1.53.
}

45 In his defense, Socrates denies that he is a sophist precisely on the basis of the fact that he does not own his poverty, "And had I gained anything, or if my exhortations had been paid, there would have been some sense in that: but now, as you will perceive, not even the impudence of my accusers dares to say that I have ever exacted or sought pay of anyone; they have no witness of that. And I have a witness of the truth of what I say; my poverty is a sufficient witness." (Plato, Apology, 31bc)

46 DL, 1.28 . consideration, I at last thought of a method of trying the question. I reflected that if I could only find a man wiser than myself, then I might go to the god with a refutation in my hand..$^{47}$

Notice the logical nature of the difficulty here. Take, for example, the following two statements:

(1) Socrates is wise.

(2) Socrates is not wise.

The god asserts that Socrates is wisest among the Athenians, and the god does not lie (as he himself testifies). Hence, (1) must be true. Contrariwise, Socrates asserts that he is not wise (viz., I have no wisdom, small or great). Assuming then that (2) is also true, a contradiction results. This at least seems to be the way in which Socrates reads the oracle's pronouncement. For he states that he sought to refute the oracle. But this can only mean that he sees some contradiction between what he knows (or believes) about himself and what the god deems to be the case. Following cross-examination of the renowned citizens of Athens, Socrates eventually comes to the conclusion that the god has spoken truly. Whereas others profess to know, when in fact they do not know, of himself he states that: "I neither know nor think that I know." 48

In other words, his knowing that he is not wise serves as a sufficient condition for confirming the oracle's pronouncement that he is wise:

1. Anyone who knows that they are not wise, must be wiser than another who falsely believes that they are wise.

2. Socrates knows that he is not wise.

3. Therefore, Socrates must be wiser than another who falsely believes that they are wise.

4. Therefore, Socrates must be wise. ${ }^{49}$

But with this conclusion, we are led straight back to our earlier problem. How can Socrates be both wise and simultaneously not wise? To resolve this difficulty, we do well to consider once again the above statements (1) and (2). Socrates is both wise and not wise, which is a contradiction. But what if the two predicates (wise) in each sentence are not intended in the same way and sense? What if their relative sense is instead analogical? From such a perspective, Socrates could be both wise (1) and not wise (2), and the contradiction would be resolved.

\footnotetext{
47 Plato, Apology, 21bc.

48 Plato, Apology, 21d.

49 The inference from 3 to 4 follows from the fact that being wiser than another implies that one must have at least a minimal amount of wisdom. In like fashion, if $x>y$, and if $y$ is 0 , then it is false to contend that $x$ is 0 . For the assertion to be true, $x$ must be some number greater than 0 .
} 
What then is meant by 'wise' in each sense? The above considerations quickly reveal the answer. Thales and Chilon refuse the gift of the tripod. Pythagoras refuses the label of 'wise one', suggesting that only the gods are wise. For a parallel example, in the fragments of Heraclitus we read that, "The wisest man is an ape compared to God."50 In like fashion, Socrates contends that:

For on each occasion those who are present think I am wise in the matters in which I confute someone else; but the fact is, gentlemen, it is likely that the god is really wise and by his oracle means this: "Human wisdom is of little or no value." ${ }^{\text {51 }}$

From the above examples, we see that the two predicates 'wise' differ in sense according as they are predicated of either the human being or of the gods. Socrates is wise as a human being is wise (finite wisdom), but he is not wise as the gods are wise (infinite wisdom). ${ }^{52}$ The contradiction is thus resolved.

Still, the story does not end here. The Socratic recognition of ignorance, as I see it, represented also a major shift in early Greek thought. From the pronouncement of the oracle to the subsequent trial and execution of Socrates, philosophy as a distinct pursuit originates. The pursuit is likewise articulated precisely in relation to the above distinction. Philosophy originates in the recognition of human ignorance coupled with the pursuit of something more, indeed, something divine. Hence, Pythagoras does not end with-I am not wise (sophos). To the contrary, the denial is followed by the affirmation-I am a lover of wisdom (philosophos). In like fashion, Socrates denies that he is wise, and following his elenchic efforts, philosophy as the pursuit of infinite wisdom, is born.

\section{Aristotle and the Classical Paradigm}

Although the concept of infinite wisdom was long implicit in early Greek thought, and although Socrates would be instrumental in helping to elucidate the difference between finite and infinite wisdom, it is not until Plato, and later Aristotle, that the notion would receive more direct and,

50 See fragment $(98,99)$ of John Burnet's Early Greek Philosophers, $3^{\text {rd }}$ Edition (London, A\&C Black, 1920), p. 103.

\section{Apology, 23a.}

52 Brickhouse and Smith arrive at a similar conclusion. See, especially Chapter 2 of, Thomas C. Brickhouse and Nicholas D. Smith, Plato's Socrates (Oxford: Oxford University Press, 1996). A competing account can be seen in Christopher King, "Wisdom, Moderation, and Elenchus in Plato's "Apology"," Metaphilosophy 39:3 (2008), 345-362. Other significant accounts can be found in, Gerasimos Santas, "The Socratic Paradoxes", The Philosophical Review 73:2 (1964), 147-164; also Chapter 1 of, Gregory Vlastos and Daniel W. Graham, Studies in Greek Philosophy, Vol. 2: Socrates, Plato, and their Tradition, ed. by Daniel W. Graham (Princeton University Press, 1996). as it were, explicit treatment. In the Republic, for example, Plato's concept of the philosopher-king serves in a way as the culmination of the ancient ideal of the all-wise and just ruler. ${ }^{53}$

Alternatively, the concept of philosophy as the pursuit of a higher, divine-like wisdom, can be seen in the cave allegory, where the good (agathon) serves as the pinnacle of the prisoner's ascent..54 Alternatively, in the Symposium, an analogy is drawn between Eros, an intermediate being (daimon) who is the daughter of poverty (penia) and plenty (poros). ${ }^{55}$ Akin to the philosopher as one who seeks that which transcends finitude, so Eros is caught between (metaxu) finitude and the longing for the eternal and divine. ${ }^{56}$ Although other examples of the pursuit of infinite wisdom may no doubt be identified in the works of Plato, it is the account of Aristotle that is of chief interest in what follows.

For example, in Book VI of the Nicomachean Ethics, Aristotle discusses the intellectual virtues, including the nature of wisdom (chapters 7-8). He suggests first that as the combination of insight (nous) and science (episteme), wisdom (sophia) must be, "the most finished of the forms of knowledge". ${ }^{57}$ He further distinguishes prudence (phronesis) from wisdom proper (sophia). ${ }^{58}$ Whereas the former deals with action and what is of advantage to the human being, the latter offers no such advantage other than the knowledge derived from it's exercise, noting in particular, that, "they

53 For a larger discussion see, C.D.C Reeve, Philosopher-Kings: The Argument of Plato's Republic (Indianapolis: Hackett Publishing Company, 2006); also, Darrell Dobbs, "Plato's Paragon of Human Excellence: Socratic Philosopher and Civic Guardian," The Journal of Politics 65:4 (2003), 10621082. Interestingly, according to Chroust, Aristotle in fact objected to Plato's concept of the philosopher-ruler for the reason that, as Aristotle purportedly suggests, philosophers ought not to be kings, but rather advisors to kings. See, Anton-Hermann Chroust, “Aristotle's Criticism of Plato's "Philosopher King"," Rheinisches Museum für Philologie, Neue Folge, 111:1 (1968), 16-22.

54 Plato, Republic, 514a-520a. This is further confirmed by Socrates who earlier (508e) states that he cannot define the good but only the form of it.

55 Plato, Symposium, 203be. For further discussion of the link between Eros and philosophy, see Mark Holowchak, "Wisdom, Wine, and WonderLust in Plato's Symposium," Philosophy and Literature 27:2 (2003), 415427.

56 I am thinking here of Desmond's concept of the between (metaxu). See, for example, William Desmond, Being and the Between (NY: State University of New York Press, 1995).

57 Aristotle, E.N., 1141a16-19. All translations for Aristotle's texts are from Johnathan Barnes, The Complete Works of Aristotle, Vol 2, ed. by Jonathan Barnes (Princeton University Press, 1984). For a general discussion of Aristotle's account of Wisdom in the Nicomachean Ethics, see, Chapter 9 of Carlo Natali, The Wisdom of Aristotle (NY: SUNY Press, 2001).

58 (1141a25-30). I avoid the traditional division between 'practical' and 'theoretical' wisdom for the reason that the characterization tends to over-intellectualize the latter kind, which Aristotle also links to happiness or well-being. I therefore translate the Greek in a more literal sense, using 'prudence' for phronesis and 'wisdom' for sophia. 
know things that are remarkable (peritta), admirable (thaumasta), difficult (chalepa), and divine (daimonia), but useless (achresta); viz., because it is not human goods that they seek." 59

In Book $\mathrm{X}$, chapters 7-8, the account of wisdom is brought into alignment with the highest happiness or wellbeing (eudaimonia) through the activity of contemplation (theoria). ${ }^{60}$ Contemplation is further described as the most excellent (kratiste), continuous (synechestate) or enduring (atryton), pleasant (hediste), self-sufficient (autarkes), and leisurely (scholastikon) of activities. ${ }^{61}$ He later links contemplation to the chief activity of the gods, ${ }^{62}$ and following this, in a significant passage which I quote in full, points out the limitations inherent in the human pursuit of infinite wisdom:

But such a life would be too high for man; for it is not in so far as he is man that he will live so, but in so far as something divine is present in him; and by so much as this is superior to our composite nature is its activity superior to that which is the exercise of the other kind of virtue. If reason is divine, then, in comparison with man, the life according to it is divine in comparison with human life. But we must not follow those who advise us, being men, to think of human things, and, being mortal, of mortal things, but must, so far as we can, make ourselves immortal, and strain every nerve to live in accordance with the best thing in us; for even if it be small in bulk, much more does it in power and worth surpass everything. ${ }^{63}$

Further elucidations of the nature of infinite wisdom are provided in the first two chapters of Book I (Alpha) of the Metaphysics, with specific emphasis placed upon analysis of the attributes of the sage. ${ }^{64}$ In chapter 1 , Aristotle initiates with a general account of the axiological structure of knowledge. He suggests that although knowledge begins with experience and the particular, it is nonetheless completed in rational insight and the universal. A number of comparisons as well as analogies are drawn, viz., between the disconnected in

\section{Aristotle, E.N., 1141b3-8. \\ 60 Aristotle, E.N., 1177a12-19. \\ 61 Aristotle, E.N., 1177a20-1177b25. \\ 62 Aristotle, E.N., 1178b22-25. \\ 63 Aristotle, E.N., 1177b26-1178a3.}

64 Although the account of wisdom in the Metaphysics is classically tied to the account of metaphysics as precisely the science of wisdom, I here omit discussion of this issue. Indeed, to enter into the complexities of this problem would draw us into larger historical issues regarding the (often disputed) unity of Aristotle's text, not to mention the interconnections between metaphysics, theology, and the specialized sciences. Such a discussion I here set aside as a separate inquiry. contrast to the connected experience (empeiria) of animals versus the human being, ${ }^{65}$ and also, between those who live according to experience and the particular (kath' hekaston) in contrast with those who live according to art (techne) and the universal (katholou). ${ }^{66}$ Again, as the manual laborer is to the master-craftsman (architekton), so the wise person is to the individual of experience. Whereas the former know the why (dioti) and cause (aition) for which they work, the latter do not, and act as if blindly and by habit (ethos).$^{67}$ I call this last illustration, the analogy of the knowledge-architect: As the architect provides the blueprint according to which the manual laborers 'blindly' work, so too the knowledgearchitect discerns and provides the principles and causes that serve as assumptions for which the other sciences 'blindly' labor.

In chapter 2, Aristotle examines the nature of infinite wisdom. His account there likewise serves as a kind of synthesis of various points cited in the above passages and texts. I call this account the "classical paradigm" of infinite wisdom. It is the paradigm of philosophy as pursuing infinite wisdom according to the three attributes of the domain, dominion, and dignity of wisdom. ${ }^{68}$ In what follows, I offer a description of each attribute, providing textual evidence where relevant.

First, there is the domain of wisdom. This attribute corresponds to the seemingly disparate but quite manifold skills of the sages earlier reported in Diogenes Laertius. Here, such skills are brought beneath a grand synthesis, that is called 'wisdom'. Aristotle states that the domain of infinite wisdom is such that the sage will, "know all things (epistasthai panta), as far as possible". ${ }^{69}$ The statement is,

65 Aristotle, Met., 980b25-27. For a discussion of Aristotle's account of wisdom in the Metaphysics, see Seth Bernardete, "On Wisdom and Philosophy: The First Two Chapters of Aristotle's "Metaphysics" A," The Review of Metaphysics 32:2 (1978), 205-215.

66 Aristotle, Met., 981a15-18.

67 Aristotle, Met., 981a31-981b9.

68 As Aristotle's works are appropriated in later medieval thought, so too the classical paradigm. See, especially, Thomas Machula, "Theology as Wisdom: Renaissance and Modern Scholastic Commentaries on Aquinas," American Catholic Philosophical Quarterly 93:2 (2019), 211-225. Machula explicitly identifies (p. 213) the threefold paradigm (as here discussed) central to issues identified among the later commentators of Thomas Aquinas. I note that in medieval thought, the classical paradigm is in fact appropriated through the guise of Theology. For an account of the difference between the account of wisdom as understood in Aristotle and alternatively Aquinas, see Edmond Eh, "Wisdom in Aristotle and Aquinas: From Metaphysics to Mysticism," Existenz 12:2 (2017), 19-24. Further distinctions regarding the difference between the Aristotelian account of wisdom and early medieval accounts (e.g., Augustine and Boethius) relative also to NeoPlatonism can be seen in Heather M. Erb, "The Varieties of Wisdom and the Consolation of Philosophy," Logos: A Journal of Catholic Thought and Culture 15:23 (2012), 161-189.

69 Aristotle, Met., 982a9. 
however, immediately qualified by the addition that such knowledge does not imply that the sage will know also all the particulars (kath' hekaston) of things. ${ }^{70}$ To the contrary, the sage seeks to acquire a knowledge of the starting points of knowledge (see below). As all other knowledge advances on the basis of such starting points, to that extent, the sage therefore indirectly examines all things. Sage-knowledge is therefore generalist in nature, and likewise takes the form of a scientia universalis.

Second, there is the dominion of wisdom. Here the wise utterances of the sages find their place. In a race, the runners begin at the starting line, and advance round the track to the finish line, which is incidentally the same place as the starting line. In like fashion, knowledge proceeds from starting points, and advances back towards such starting points. ${ }^{71}$ This expresses the nature of wisdom as proceeding from and to first principles (archai) and causes (aitiai), of which Aristotle notes, "the knowledge of which is wisdom (sophia)". ${ }^{72}$ In this sense, wisdom encompasses what might be taken as the axioms of all that which can be known. Within a formally deductive system, for example, axioms serve as the basic starting points or assumptions from which all other conclusions are drawn. In analogous fashion, the first principles and causes examined by the sage serve as the starting points or axioms governing the several ancillary or specialized sciences. From this perspective, such wisdom and the wise become also instructive of the other disciplines. Aristotle thus notes that, "the wise man must not be ordered but must order".73 Here the analogy of the knowledgearchitect comes again into play: Whereas wisdom labors for its own sake, the other sciences labor for the sake of wisdom. In consequence, wisdom is the most authoritative science, this serving as a further qualification of dominion. ${ }^{74}$

Third, there is the dignity of wisdom. Two points are here identified. The first involves the link between wisdom and the free exercise of inquiry. Echoing earlier remarks in the Nicomachean Ethics regarding both the inutility of wisdom as well as leisure, Aristotle states that wisdom is "desirable on its own account and for the sake of knowing". ${ }^{75}$ Wisdom is further disassociated from productive science $\mathrm{ou}$ poieteki) for the reason that the earliest philosophers (i.e., the sages) inquired out of wonder (thaumasantes) and in order to escape from ignorance (ten agnoian), and so too,

\footnotetext{
70 Aristotle, Met., 982a10.

71 Aristotle, E.N., 1095a30-35.

72 Aristotle, Met., 982a6.

73 Aristotle, Met., 982a19.

74 Aristotle, Met., 982b5-6.

75 Aristotle, Met., 982a15-16.
}

without any practical or utilitarian purpose (ou chreseos). ${ }^{76}$ In this, a link may be drawn between Aristotle's account and the earlier discussion of Socratic ignorance ("I know that I do not know"). It is in ignorance as well as perplexity at such ignorance that the search for wisdom commences. Finally, Aristotle draws an essential analogy that serves to highlight the dignity of wisdom, which is that one who pursues such wisdom is free in the highest degree and sense:

Evidently then we do not seek it for the sake of any other advantage; but as the man is free, we say, who exists for his own sake and not for another's, so we pursue this as the only free science, for it alone exists for its own sake. ${ }^{77}$

The second point regards the dignity of the kinds of objects that wisdom examines. Among the starting points of knowledge, there are included the final causes (telos) of explanation such as the good (to agathon), ${ }^{78}$ which Aristotle notably characterizes in the Nicomachean Ethics as that which all things naturally desire. ${ }^{79}$ Again, wisdom examines not only the object of natural desire, but also divine matters, including the divine itself ( $o$ theos). In these two examples, the dignity of wisdom arises as an inquiry into certain kinds of objects that stand highest among all other things, first, as the aim of all human desire, and second, as the most splendid and marvelous object(s) of contemplation.

Finally, Aristotle notes that, in the end, such heights of infinite wisdom may well lie beyond our finite capacities, being rather the possession of, "either god alone...or God above all others". ${ }^{80}$ Of course, that the perfection of infinite wisdom is beyond us, does not imply that the human being cannot aspire to some approximation to it. To the contrary, we ought to seek such wisdom, and in doing so, may even achieve some degree of excellence (virtue) in its pursuit.

\section{The Performance of Infinite Wisdom}

Between the finite and the infinite stands an infinite gap. If the human being, as finite, pursues a wisdom that is infinite, then there seems to be no possibility of transcending the gap between the two. In comparison to the infinite, any positive finite number is next to nothing (e.g., $n / \infty=0$, where $\mathrm{n}$ is a finite number). Nevertheless, a finite number differs

\footnotetext{
76 Aristotle, Met., 982b11-12; 20-22.

77 Aristotle, Met., 982b24-27.

78 Aristotle, Met., 982b5-7.

79 Aristotle, E.N., 1094a1-3.

80 Aristotle, Met., 983a10. See also Bryan C. Reece, "Aristotle on Divine and Human Contemplation," Ergo 7:4 (2020). DOI: http://dx.doi. org/10.3998/ergo.12405314.0007.004. Also, Chapter 3 of C.D.C. Reeve, Action, Contemplation, and Happiness: An Essay on Aristotle (Harvard University Press, 2012).
} 
from zero in being a positive finite quantity. In like fashion, even if the human attainment of wisdom is next to nothing in comparison with the divine, in itself, there is a certain excellence in one who achieves such gains. It is in this way that we might consider the pursuit of infinite wisdom as a virtue (arete) whose excellence may to some extent be finitely achieved. Of course, the finite individual who achieves such excellence, as already noted, does so finitely. But as the finite achievement is also an achievement relative to the pursuit of the infinite, it is also an achievement that to some extent transcends finitude.

A simple analogy will help to explain my meaning here. Looking around in the room, a number of objects can be seen - a coffee mug, a cell phone, spectacles, a book. These objects lay within the range of my finite senses. I can reorder the objects in my mind, alter their colors, count themfour. But what is truly spectacular in all of this is the human capacity to immediately leap beyond the limits of finitude. At one moment, I am reflecting upon a finite set of objects in the room. At another moment, my mind can lay hold of grand abstractions, infinite numbers, absurd and contradictory objects, ceaseless space, absolute nothingness, eternity, permanency, and perfection. With the ancients, we might say, that in such reflections the mind becomes like unto its object. If this is the case (if only metaphorically), then it follows that in such thoughts, the human mind in some sense extends beyond the limits of finitude.

Earlier in the Nicomachean Ethics, Aristotle links wisdom to intellectual virtue. ${ }^{81}$ Intellectual virtue itself is a type of excellence. So the philosopher who pursues, and alternatively attains a certain degree of excellence in the pursuit of infinite wisdom, must inevitably exhibit such wisdom. But as such a philosopher qua sage is admittedly finite, to that extent, the exhibition of wisdom must itself be both finite and yet extending beyond finitude, insofar as it involves a reaching out into infinitude. For this reason, such an exhibition, which lies between the finite and the infinite, I call monumental. Alternatively, the sage who exhibits such wisdom, I call a monumental sage.

Recognizing at least the possibility of such a sage, one is compelled to ask, have there ever been such sages? If so, then what would the performances of such monumental sages be? A possible response is now available to us. Aristotle's account of wisdom serves precisely as the paradigm of infinite wisdom. In particular, Aristotle himself may be produced as an historical example of one who exhibits wisdom monumentally. Consider the following: It was Aristotle who first synthesized the scattered thoughts of his predecessors, putting together an early scientific vision that would inform

81 Aristotle, E.N., 1103a1-5. a multitude of generations for almost two millennia. ${ }^{82}$ Although fundamentally incomplete, the AristotelianPtolemaic universe nonetheless had a predictive value that would serve as the backbone for later modern scientific advances. ${ }^{83}$ Still more, it was Aristotle who, if not being the first biologist, was at least the first to lay down the theoretical rigors of that science. He developed the first classification system, indeed, the very concept of such a system originated in his analyses of the nature of categorical sameness and difference.$^{84}$ His many researchers conducted at the Lyceum are likewise still with us: Long scientific inquiries that show detailed collections and analyses of diverse species spanning plant to animal kingdom. It was Aristotle (e.g., the Posterior Analytics) who further conferred upon western civilization the first paradigm of what a science is and ought to consist in. ${ }^{85}$ He bequeathed upon civilization a formal structure for understanding causality. He developed the first formal rules of logic, the first philosophy of science, the first rigorous division of the sciences, and so on. He likewise developed a system of ethics, politics, aesthetics, poetics, rhetoric, dialectics, metaphysics - and all of this at the initial dawning of western intellectual thought.

To conclude, two points may be drawn from the above observations. First, although Aristotle's intellectual capacities reached into the ability to fix his mind upon specialized forms of research (as instanced in his scientific works), he was far more than a specialist. Akin to the pre-Socratic sages, he was a generalist of the highest refinement (domain). Still more, he was a generalist who sought to synthesize human knowledge from the ground up (dominion), reaching out to the divine (dignity), and in a way that was averse to mere flights of fancy, but sought instead to remain ever consonant with the sciences of his time. His was a science and yet it was far more than science. It was a philosophy in pursuit of infinite wisdom.

Second, the achievements of Aristotle were cultural achievements. Aristotle was the fruit, his predecessors the

82 For an account of these early developments, see, G.E.R. Lloyd, Early Greek Science: Thales to Aristotle (London: W.W. Norton \& Company, 1974).

83 Indeed, the scientific contributions of Aristotle are still very much implicitly present within the natural sciences. See, e.g., Edward Feser, Aristotle's Revenge: The Metaphysical Foundations of Physical and Biological Science (Neunkirchen-Seelscheid: Editiones Scholasticae, 2019).

84 See, e.g., Eleni Voultsiadou, et al., "Aristotle's scientific contributions to the classification, nomenclature and distribution of marine organisms," Mediterranean Marine Science 18:3 (2017): 468-478. See, e.g., Mariska Leunissan, Explanation and Teleology in Aristotle's Science of Nature (Cambridge: Cambridge University Press, 2010).

85 An interesting application of Aristotelianism in the modeling of modern scientific concepts can be seen in William A. Wallace, The Modelling of Nature: Philosophy of Science and the Philosophy of Nature in Synthesis (The Catholic University Press, 1996). 
seed and soil. Aristotle stood upon the shoulders of other giants-Plato, Socrates, the pre-Socratic sages, Egyptian and Persian influences, and so on. Yet he likewise strode far above and beyond them. The time was ripe for wisdom, and Aristotle was among the greatest intellectual fruits that flowered forth from the Golden Age of Greece. In his work we see a creative genius that both uncovered and systematized the ancient worldview. In Aristotle, we see not one or two achievements, but a multitude of achievements; and we see such achievements not in one or two or even three distinct fields of inquiry, but again, in a multitude of such fieldsfrom physics to biology to logic to metaphysics to aesthetics to ethics to political science. So even Dante recognized his achievements in the Divine Comedy:

When I had lifted up my brows a little, The Master I beheld of those who know, Sit with his philosophic family. ${ }^{86}$

86 Dante, Inferno, 4.130-132, translated by Henry Wadsworth Longfellow. Retrieved from https://www.gutenberg.org/files/1001/1001-h/1001-h. htm.

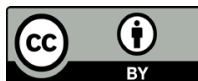

